\title{
Nomenclature of Antigens of Group B Streptococci
}

\author{
J. HENRICHSEN, ${ }^{*}$ PATRICIA FERRIERI, ${ }^{2}$ JARMILA JELINKOVA,${ }^{3}$ W. KÖHLER, ${ }^{4}$ AND W. R. MAXTED \\ Statens Seruminstitut, DK-2300 Copenhagen, Denmark ${ }^{1}$; University of Minnesota Medical School, Minneapolis, \\ Minnesota 55455'; Institute of Hygiene and Epidemiology, Prague, Czechoslovakia $;$ Z Zentralinstitut für Mikrobiologie und \\ Experimentelle Therapie, Jena, German Democratic Republic ; and 30 Buckingham Gardens, Edgware, Middlesex, \\ England $^{5}$
}

We propose a revision of the nomenclature of the antigens of group B streptococci.

After a contribution by Jelinkova on the nomenclature of antigens of group B streptococci (GBS) at the Workshop on Neonatal Group B Streptococcal Infections held in Lund, Sweden, 22 to 25 August 1983 , a discussion of the subject resulted in a request to us to discuss the matter further and, if possible, to propose a revision. The following summary of our reflections was presented to all members of the Workshop at a later stage.

"The main reason why existing nomenclature sometimes creates confusion is that the polysaccharide and protein antigens of GBS are not named independently, in contrast to the antigens of many other bacterial species, e.g., Haemophilus influenzae, Neisseria meningitidis, and Streptococcus pneumoniae. The late Rebecca Lancefield felt that if antibodies directed against an antigen conferred passive protection in the mouse model, then the antigen deserved status as a type antigen. Thus, the present type Ic was established as a separate type because in addition to the polysaccharide antigen Ia, strains of this type carry a protein antigen, antibodies against which provide partial protection in the mouse. This protein antigen, which originally was also found in type Ib strains, is now most often called Ibc even though it may also be possessed by strains of types II, III, and IV. It has also been called Ic.

"Changes of nomenclature, obviously, should be as few as possible. In conformity with the nomenclature of other capsulated streptococci, Streptococcus pneumoniae, and $S$. suis, it was proposed to consider the polysaccharide antigens of GBS as type antigens and the protein antigens as additional antigenic markers useful for supplementary serological characterization of types. It was further proposed to designate the capsular polysaccharide type antigens by Roman numerals (in two cases followed by a small letter) and protein antigens by letters and to separate these designations by a virgule. Consequently, only the designation of protein

TABLE 1. Types of GBS antigens ${ }^{a}$

\begin{tabular}{|c|c|}
\hline $\begin{array}{l}\text { Present } \\
\text { designation }\end{array}$ & $\begin{array}{c}\text { Proposed } \\
\text { designation }\end{array}$ \\
\hline$\ldots \ldots \ldots \ldots \ldots \ldots \ldots \ldots \ldots \ldots \ldots$ & $\mathrm{Ia}$ \\
\hline Ib $\ldots \ldots \ldots \ldots \ldots \ldots \ldots \ldots \ldots \ldots \ldots$ & $\mathrm{Ib}$ \\
\hline Ic $\ldots \ldots \ldots \ldots \ldots \ldots \ldots \ldots \ldots \ldots$ & $\mathrm{Ia} / \mathrm{c}$ \\
\hline $\mathrm{II} \ldots \ldots \ldots \ldots \ldots \ldots \ldots \ldots \ldots \ldots$ & II \\
\hline 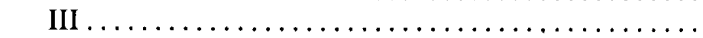 & III \\
\hline IV $\ldots \ldots \ldots \ldots \ldots \ldots \ldots \ldots \ldots \ldots$ & IV \\
\hline
\end{tabular}

${ }^{a}$ Protein antigens $\mathrm{c}, \mathrm{R}$, and $\mathrm{X}$ are carried singly or in combination by many strains.

\footnotetext{
* Corresponding author.
}

antigen Ibc (or Ic) needs to be changed to $\mathrm{c}$, as previously suggested by Jelinkova (1) (Table 1).

"This way, type Ib becomes Ib/c if, in addition to the polysaccharide antigen $\mathrm{Ib}$, it also carries protein antigen $\mathrm{c}$, and type Ic becomes $\mathrm{Ia} / \mathrm{c}$ because (per definition) it carries polysaccharide antigen Ia and protein antigen c. A type II strain that carries protein antigen $c$ is designated II/c, a type III strain that carries protein antigens $c$ and $R$ is designated $\mathrm{III} / \mathrm{c}, \mathrm{R}$, and a strain which is nontypable (NT) with available antisera against polysaccharide type antigens and carries the $R$ antigen is designated NT/R.'

The members of the Workshop unanimously agreed to this proposal, which involves a minimum number of changes and is unequivocal, and they intend to follow it in future publications. The hope was expressed that other members of the scientific community will also consider doing so.

\section{ACKNOWLEDGMENTS}

The Workshop, in addition to the authors, had the following participants: B. F. Anthony, University of California at Los Angeles Medical Center, Torrance; E. Ayoub, University of Florida, Gainesville; C. J. Baker, Baylor College of Medicine, Houston, Tex.; L. Bevanger, University of Trondheim, Trondheim, Norway; K. Boyer, Michael Reese Hospital and Medical Center, Chicago, Ill.; K. K. Christensen, University Hospital, Lund, Sweden; P. Christensen, University of Lund, Lund, Sweden; H. C. Dillon, University of Alabama, Birmingham; C. S. F. Easmon, WrightFleming Institute, London, England; M. S. Edwards, Baylor Cólege of Medicine, Houston, Tex.; G. Faxelius, Karolinska Sjukhuset, Stockholm, Sweden; G. W: Fischer, Uniformed Services University of the Health Sciences, Bethesda, Md.; S. P. Gotoff, Michael Reese Hospital and Medical Center, Chicago, Ill.; B. M. Gray, University of Alabama, Birmingham; G. Hahn, Institut für Hygiene, Kiel, Federal Republic of Germany; W. Handrick, Karl Marx Universität, Leipzig, German Democratic Republic; V. G. Hemming, Uniformed Services University of the Health Sciences, Bethesda, Md.; H. R. Hill, University of Utah, Salt Lake City; S. E. Holm, University of Umeå, Umeå, Sweden; N. E. Jensen, State Veterinary Serum Laboratory, Ringsted, Denmark; D. L. Kasper, Beth Israel Hospital, Boston, Mass.; K. S. Kim, University of California at Los Angeles Medical Center, Torrance; N. J. Levy, Channing Laboratory, Boston, Mass.; V. Lindén, University of Lund, Lund, Sweden; R. Lütticken, Hygiene-Institut der Univers-tät Köln, Cologne, Federal Republic of Germany; R. T. MayonWhite, Public Health Laboratory, Oxford, England; A. Shigeoka, University of Utah, Salt Lake City; R. Seger, Kinderspital Zürich, Zürich, Switzerland; M. Wagner, Zentralinstitut für Mikrobiologie und Experimentelle Therapie, Jena, German Democratic Republic.

\section{LITERATURE CITED}

1. Jelinkova, J. 1977. Group B streptococci in the human population. Curr. Top. Microbiol. Immunol. 76:127-165. 